\title{
Growth, Yield, Nutrient Content and Fruit Quality of Carica papaya L. Under Controlled Conditions. II. Boron Effects ${ }^{1}$
}

\author{
Agripino Párez and Norman F. Childers ${ }^{2}$
}

\begin{abstract}
A sand culture greenhouse experiment was conducted with papaya, Carica papaya L., variety Blue Solo, to determine the effects of four levels of $B$ in the nutrient solution $(0.01,0.05,0.1$ (control), and $1.5 \mathrm{p} / \mathrm{m})$ on growth, fruiting and mineral content. $B$ deficiency and $B$ excess symptoms are described for leaves, petioles, central stems, and fruit. Mineral contents of leaves, petioles, and fruits are presented and discussed. Fruits receiving $0.05 \mathrm{p} / \mathrm{m} B$ in the nutrient solution were preferred. The critical level of $B$ appears to be about $20 \mathrm{p} / \mathrm{m}$ in the petioles and leaves, whereas excess B occurred at about 70 and $300 \mathrm{p} / \mathrm{m}$, respectively, for petioles and leaves. Quality components of the fruits are based on taste panel evaluation.
\end{abstract}

\section{INTRODUCTION}

The commercial papaya, Carica papaya L., is grown widely in the tropics and sub-tropics. Foliar studies on the nutrition of this plant have been made in Hawaii $(2,3,4,5,6)$, and limited field tests and recommendations in Florida (17), Hawaii $(10,11)$ and India $(18,19)$. Nutrient deficiency symptoms and studies of the foliar $\mathrm{N}$ and $\mathrm{P}$ trends are available for a generic relative in Chile, known as the Mountain papaya C. candamarcensis Hook $f .(9,12,13,14)$, which is hardy in southern California but the fruits are of little commercial value (7). Cibes and Gaztambide (8) described the mineral deficiency symptoms displayed by this plant when grown under controlled conditions.

Objectives of this study were to determine the effects of different levels of $\mathrm{B}$ in greenhouse sand culture on growth, flowering, fruiting, fruit quality and mineral content of the leaves and fruit of C. papaya.

\section{MATERIALS AND METHODS}

This experiment was conducted simultaneously with a nitrogen experiment under the same greenhouse conditions and with the same materials and methods. The $\mathrm{N}$ and $\mathrm{B}$ effects (15) data were collected similarly on the same papaya plants and are reported in separate papers as Part I and

${ }^{1}$ Manuscript submitted to Editorial Board June 26, 1980.

${ }^{2}$ Horticulturist and Professor of Horticulture, Agricultural Experiment Station, Mayagüez Campus, University of Puerto Rico, Río Piedras, P.R.; and Blake Professor of Horticulture, Rutgers-The State University, New Brunswick, N.J. Elizabeth F. Stier, Department of Food Science, Rutgers-The State University, assisted in conducting the sensory evaluations; Cyril B. Smith, Department of Horticulture, Pennsylvania State University, supervised the tissue analyses; and J. Richard Trout, Department of Statistics, Rutgers--The State University, assisted in planning and interpreting the statistical analyses. 
II, respectively. The four levels of $B(0.01,0.05,0.1$ and $1.5 \mathrm{p} / \mathrm{m})$ used in this study were replicated five times with female, hermaphroditic and male plants. Boron was supplied from boric acid.

\section{RESULTS AND DISCUSSION}

\section{FLOWERING AND FRUITING}

Within 20 days after differential treatments were initiated, the flower buds, regardless of sex, were the first to show deficiency symptoms in the

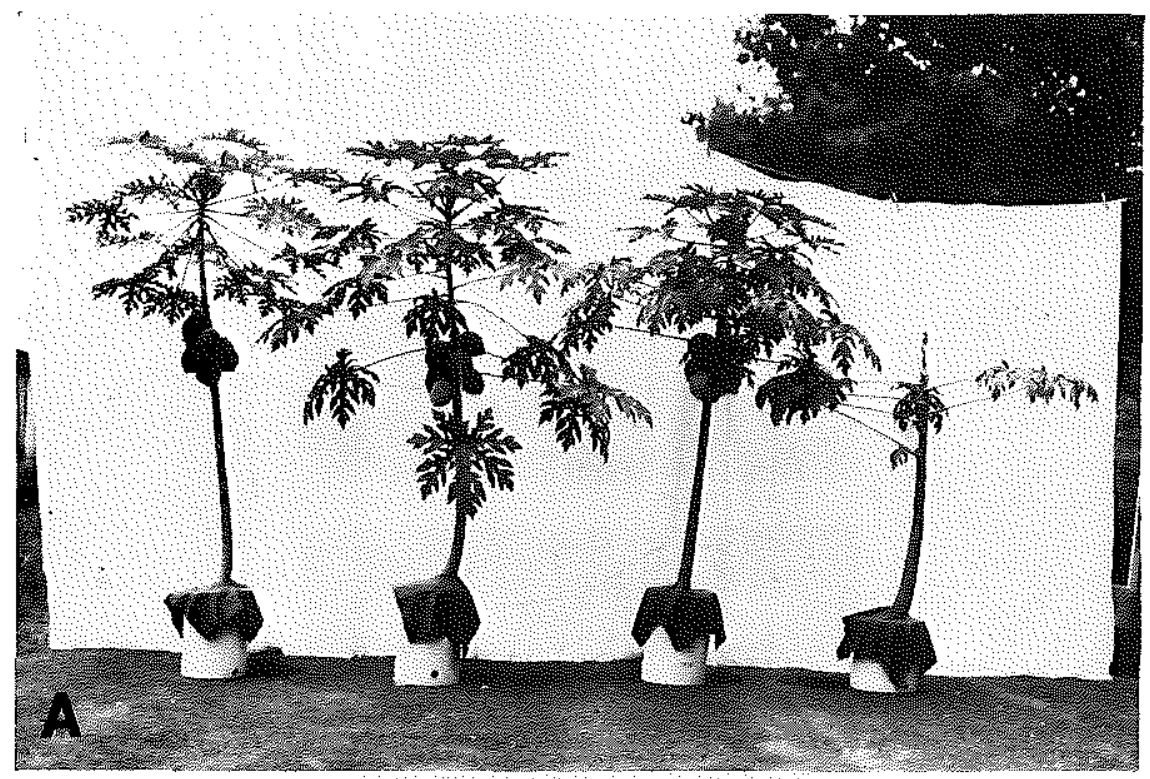

Fig. 1.-A. left to right, B levels from excess $(1.5 \mathrm{p} / \mathrm{m})$ to severely deficient $(0.01 \mathrm{p} / \mathrm{m})$; B. B-deficient terminal as shown in A at right; C. Fruits from hermaphroditic and female plants at low, normal and excess levels of B; D. Cross-section of papaya stems showing corkiness and cambial destruction at $0.01 \mathrm{p} / \mathrm{m} \mathrm{B} ; \mathrm{E}$. Abortion and dropping of male flowers (near center of picture) at the $0.01 \mathrm{~B}$ level; F. Yellowing and dropping of female flower buds at $0.01 \mathrm{p} / \mathrm{m} \mathrm{B}$; G. Right, leaf showing smaller size and tip burn due to $B$ excess at $1.50 \mathrm{p} / \mathrm{m}$; center, control; left, leaf from $0.01 \mathrm{p} / \mathrm{m} \mathrm{B}$.

lowest $0.01 \mathrm{p} / \mathrm{m}$ B dosis. A whitish exudation appeared on the youngest flower buds, which often fell before opening. Older flowers that were present before the first $B$ deficiency symptoms appeared, eventually dropped within 50 days.

On trees supplied with $0.05 \mathrm{p} / \mathrm{m}$ B many of the flowers had dropped 4 months after differential treatments. Also, fruits that had set were lumpy, misshapen and somewhat corky (fig. 1). No deficiency or other symptoms were noted on flowers or fruits on trees supplied with 0.10 or higher. 

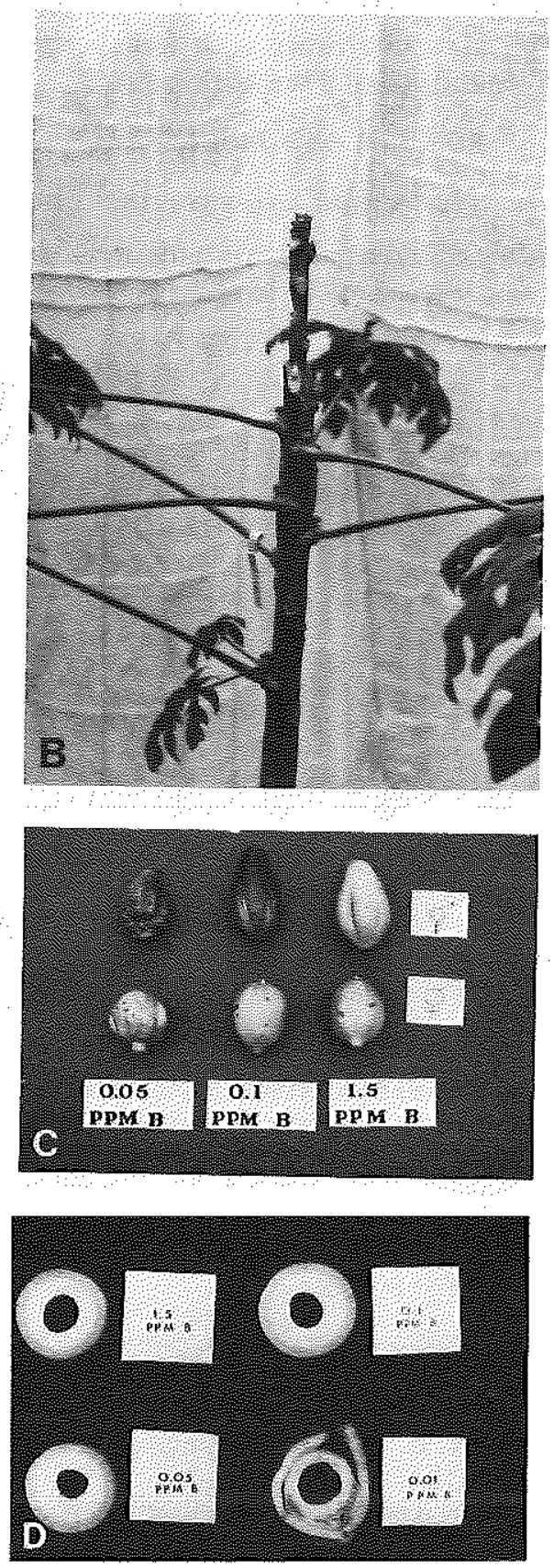


\section{GROWTH EFFECTS}

Shortly after flowering other deficiency symptoms began to appear. Ends of the petioles showed swelling with whitish exudation that dried and hardened (fig. 1). Terminal leaves down to the fifth and sixth leaf showed chlorosis. Eventually, no new leaves formed on plants supplied
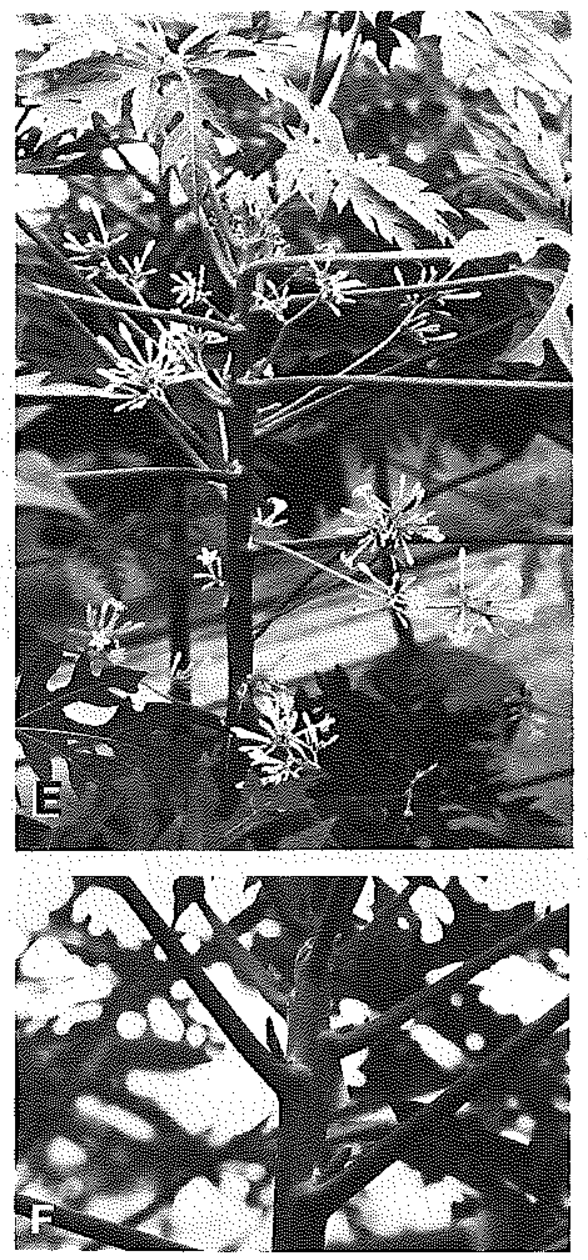

with $0.01 \mathrm{p} / \mathrm{m} \mathrm{B}$, and the younger ones became distorted (fig. 2), coarse, brittle, stiff, and in some cases the center lobe was bent downward at a $90^{\circ}$ angle due to splitting of the central vein. The younger leaves dropped prematurely. The terminal central stems cracked and showed internal corking (fig. 1). 
Plants receiving $0.05 \mathrm{p} / \mathrm{m} \mathrm{B}$ showed deficiency symptoms 6 months after differential treatments; leaves were fasciated, some dropped and the petioles were swollen and oozing at the tips, but total growth and yield of these trees were not significantly affected. No foliar symptoms were noted on control trees receiving $0.10 \mathrm{p} / \mathrm{m} \mathrm{B}$.

Forty-five days after differential treatments there were no differences in height of plants and number of nodes. When the experiment was terminated, 225 days later, there were differences in tree height (in $\mathrm{cm}$ ): $132 \mathrm{a}, 150 \mathrm{~b}, 150 \mathrm{~b}$ and $157 \mathrm{~b}$; and number of nodes: $52 \mathrm{a}, 75 \mathrm{~b}, 75 \mathrm{~b}$ and $81 \mathrm{~b}$, respectively.

Plants at the lowest $B$ dosis had thicker trunks at the base $(5.6 \mathrm{~b}, 5,15 \mathrm{a}$, $5.1 \mathrm{a}, 5.0 \mathrm{a}$ in $\mathrm{cm}){ }^{3}$ and thicker petioles at the blade base $(5.7 \mathrm{c}, 5.4 \mathrm{~b}, 5.2 \mathrm{ab}$, $5.05 \mathrm{a}$ in $\mathrm{cm}$, respectively). Number of leaves per plant were: $14 \mathrm{a}, 24 \mathrm{~b}, 27 \mathrm{~b}$ and $25 \mathrm{~b}$.

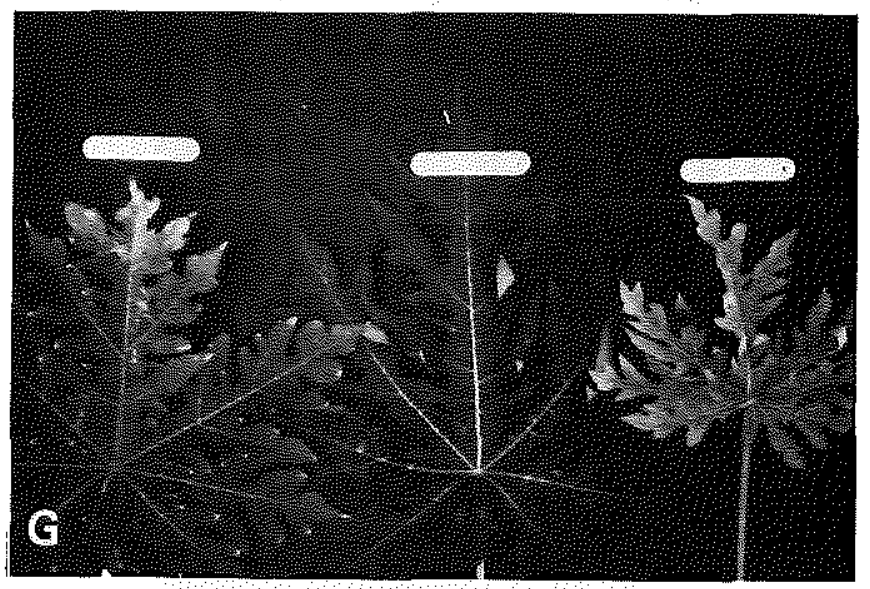

LEAF MINERAL CONTENTS

The B supply did not alter significantly the $\mathrm{Fe}, \mathrm{Cu}$ and $\mathrm{Al}$ contents in either the blades or petioles. The $N$ and $P$ in the blades were slightly and irregularly altered by the $\mathrm{B}$ levels (table 1) while the $\mathrm{Ca}, \mathrm{Mg}$, and $\mathrm{Zn}$ accumulated in both the petioles and blades of plants at $0.01 \mathrm{p} / \mathrm{m} \mathrm{B}$. Mn accumulated only in the petioles at the $0.01 \mathrm{p} / \mathrm{m}$ level. Accumulation of these nutrients in the blades and/or petioles could have been due to failure of the $0.01 \mathrm{p} / \mathrm{m} \mathrm{B}$ plants to use the nutrients in making any appreciable growth or to setting fruit.

Potassium in the blades showed little response to B supply, while $\mathrm{K}$ in

${ }^{3}$ Series of numbers refer, respectively to the levels of $B$, in the nutrient solution, ig.: 0.01 , $0.05,0.10$ (Control), $1.5 \mathrm{p} / \mathrm{m}$. 

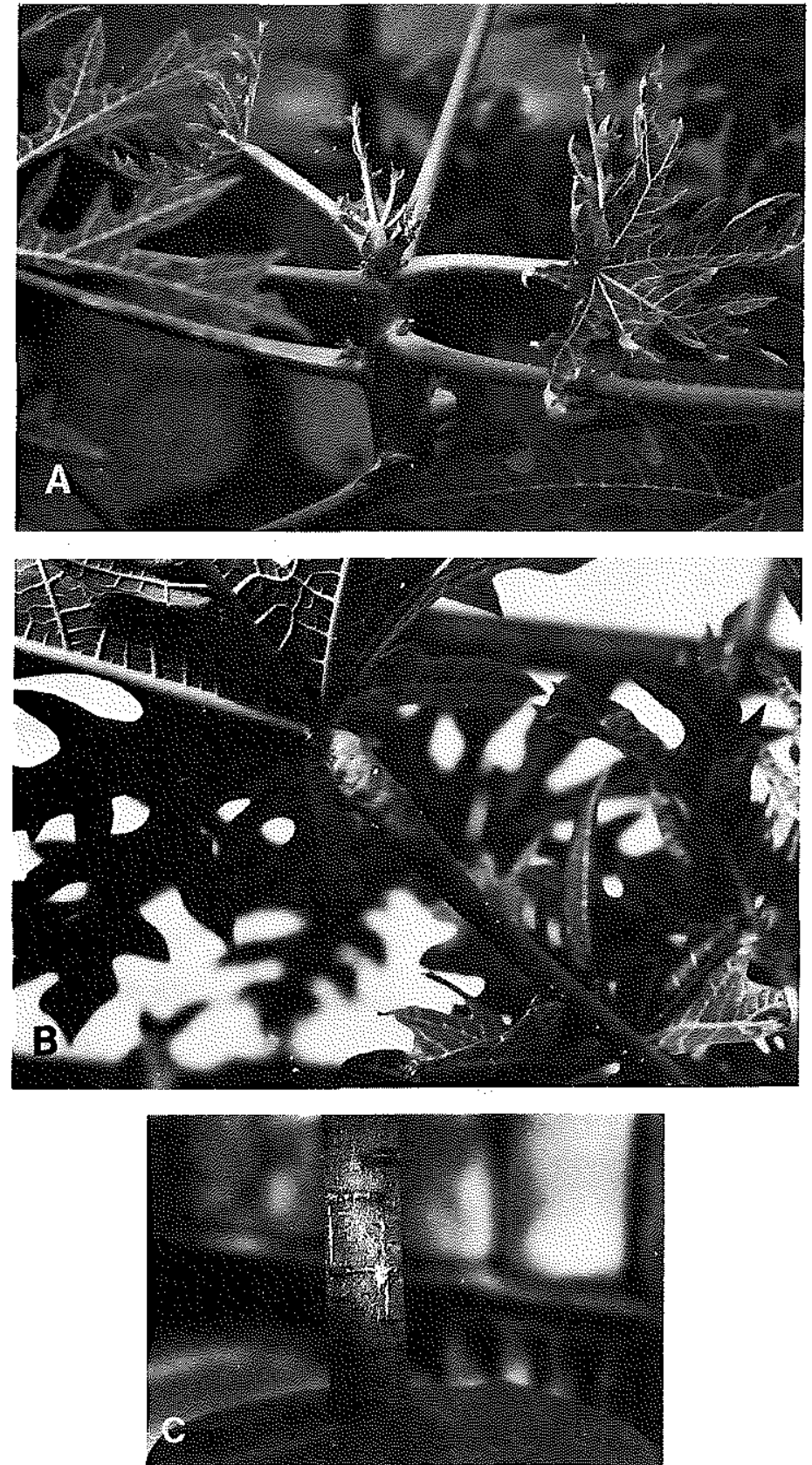

Fig. 2.-B deficiency at $0.01 \mathrm{p} / \mathrm{m}$ in the nutrient solution appeared early in the experiment showing: a) distortion of the top leaves; b) swelling of the petiole at the leaf blade attachment; c) splitting of the trunk near its base. 
TABLE 1.-Influence of $B$ levels of mineral content of blades and petioles of papaya trees at 45,105 and 225 days after treatment

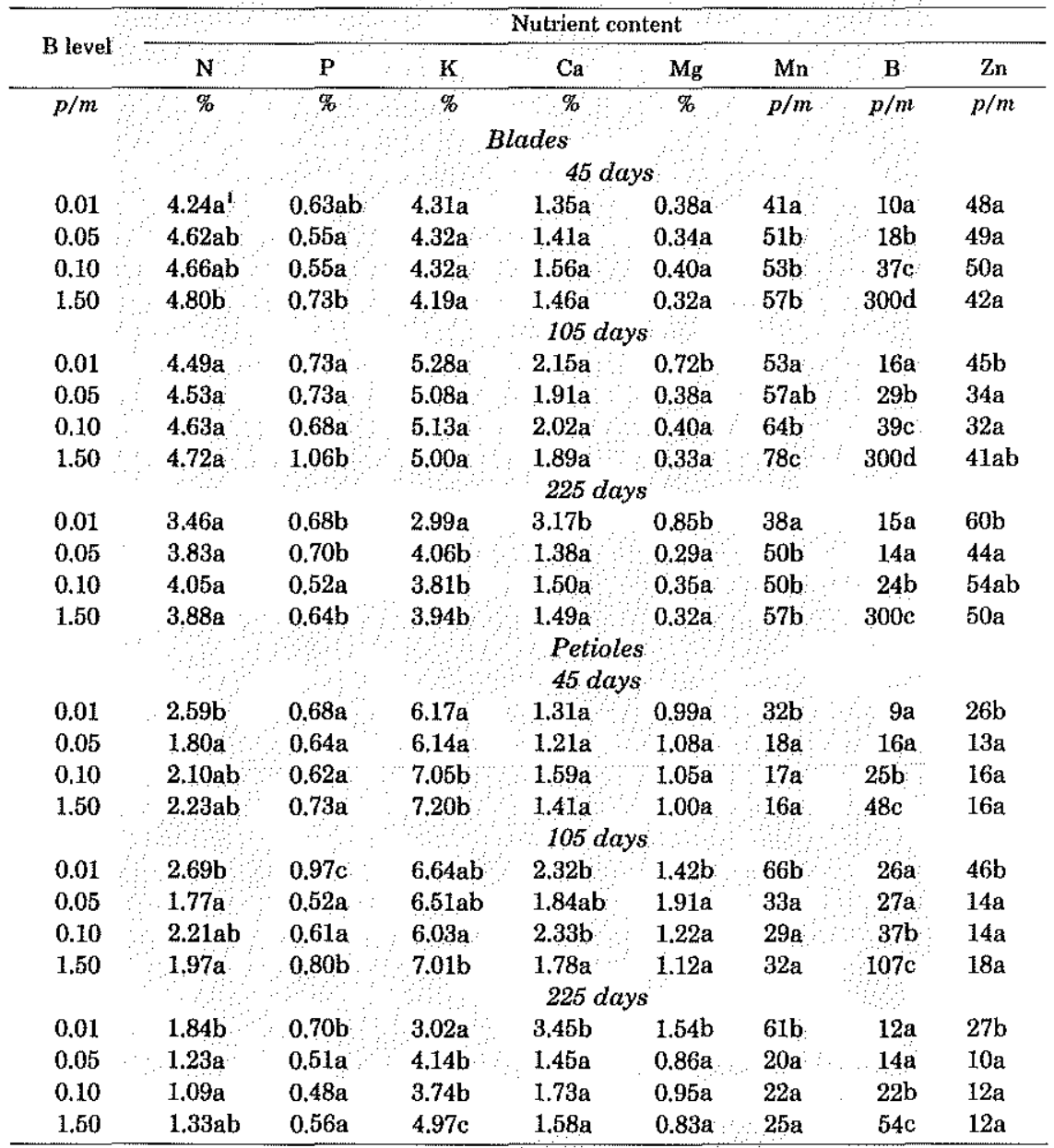

${ }^{1}$ Means in columns followed by the same letters do not differ significantly at the 0.05 level.

the petioles tended to increase with an increase in the supply of $B$, as has been noted in citrus (16).

Manganese in the blades increased with an increased supply of $B$, which indicates that the blade-Mn rather than petiole-Mn which showed no differences, may be the best index of the Mn status in the plant.

Boron in the blades and petioles increased with B supply (table 1). The average of the three samplings showed that toxicity symptoms were present (fig. 1) when the blades and petioles contained 300 and $70 \mathrm{p} / \mathrm{m}$, 
respectively. Deficiency symptoms appeared when these tissues contained less than $20 \mathrm{p} / \mathrm{m}$.

It was found that $B$ deficiency affects the youngest leaves first, whereas excess B affects the lowest leaves first. Under our conditions B deficiency at $0.01 \mathrm{p} / \mathrm{m}$ supply was more harmful to growth and fruiting than excessive $B$ at $1.5 \mathrm{p} / \mathrm{m} \mathrm{B}$. The data indicate that adequate growth and yield may be obtained when the levels of $B$ in the blades and petioles are approximately 20 to $30 \mathrm{p} / \mathrm{m}$. Muñoz et al. (13) have noted that the critical level of B in C. candamarcensis is between 20 and $30 \mathrm{p} / \mathrm{m}$. B deficiency was found to be expressed similarly in all sexes in this study.

\section{FRUIT MINERAL CONTENTS}

The only significant differences in mineral content of the fruits were the higher $\mathrm{P}, \mathrm{Mg}$ and $\mathrm{B}$ contents of trees receiving $1.5 \mathrm{p} / \mathrm{m} \mathrm{B}$ vs those supplied with 0.05 and $0.10 \mathrm{p} / \mathrm{m}$; e.g., for the $0.05,0.10$ and $1.5 \mathrm{p} / \mathrm{m}$ levels of $\mathrm{B}$, the $\mathrm{P}$ contents in percent were $0.40 \mathrm{a}, 0.36 \mathrm{a}, 0.55 \mathrm{~b}$; for $\mathrm{Mg}$ in percent, $0.26 \mathrm{a}, 0.29 \mathrm{a}$, and $0.36 \mathrm{~b}$; and for $\mathrm{B}$ in $\mathrm{p} / \mathrm{m}, 12 \mathrm{a}, 19 \mathrm{a}$, and $82 \mathrm{~b}$.

For commercial fruit production, fruits produced under controlled greenhouse conditions, do not seem to be the best index of the $B$ status of the plant. In apple, however, Askew (1) found that the fruit rather than the leaves is a more sensitive index of B status of the tree.

\section{FRUIT QUALITY}

Only the ratio of total solids to titratable acidity increased significantly as the B supply was increased from 0.05 to $1.5 \mathrm{p} / \mathrm{m}(17.0,21.3,26.7$, respectively with HSD of 7.2 at $1 \%$ ). The other quality components, such as $\mathrm{pH}$, soluble solids, titratable acidity and total solids were unaffected by B supply.

Fruits borne on plants receiving $0.05 \mathrm{p} / \mathrm{m} \mathrm{B}$ were judged by the panel as slightly better in flavor than those receiving $0.10 \mathrm{p} / \mathrm{m}$ (control). The panel preferred the fruits having the lowest ratio of soluble solids to acids. Scores were 4.0 (slightly better than control); 1.4 (control); and 4.8, (slightly poorer than the control)-(HSD at $1 \%=0.83$ ).

\section{RESUMEN}

Un experimento se llevó a cabo en invernadero con $C$. papaya de la variedad "Blue Solo" para determinar el efecto de cuatro niveles de B $(0.01,0.05,0.1$ (control) y $1.5 \mathrm{ppm}$ ) en la solución nutritiva con respecto al crecimiento, fructificación y contenido de las hojas y frutas. Síntomas de carencia y toxicidad se describen para las hojas, pecíolos, tallo central y de frutas cosechadas en plantas hembra y hermafrodita. También se informa el contenido mineral de las hojas, pecíolos y frutas.

El nivel crítico de $\mathrm{B}$ en los pecíolos y hojas está cerca de $20 \mathrm{ppm}$, 
mientras que el exceso para estos mismos órganos de la planta fue de 70 y $300 \mathrm{ppm}$, respectivamente. Las frutas se cataron para evaluar la calidad. De las plantas que recibieron $0.01,0.05,0.01$ (control) y 1.5 ppm B en la solución nutritiva, los catadores prefirieron las frutas de las que recibieron $0.05 \mathrm{ppm}$.

\section{LITERATURE CITED}

1. Askew, H. O., Chiltenden, E. and Thomson, R. H. K., 1936. The use of boron in the control of "internal cork" of apples. Part I. N. Zealand J. Sci. \& Tech. 18: 365-375.

2. Awada, M., 1969. The selection of the nitrogen index in papaya tissue analysis, Proc. ASHS 94 (6): 687-90.

3. - 1977. Critical potassium level in petioles of papaya, Hawaii Agric. Exp. Stn. Tech. Bull. 99.

4. - 1977. Relation of nitrogen, phosphorus and potassium fertilization to nutrient composition of the petiole and growth of papaya, J. Am. Soc. Hort. Sci. 102 (4): 41318.

5. - and Ikeda, W. S., 1957. Effects of water and nitrogen application on composition, growth, sugars in fruit, yield and sex expression of the papaya plants (Carica papaya L.), Hawaii Agric. Exp. Stn. Bul. 33.

6. and Long, C., 1969. The selection of the phosphorus index in papaya tissue analysis, Proc. ASHS 94 (5): 501-04.

7. Bailey, L. H., 1935. The standard encyclopedia of horticulture. Vol. 1, p. 164.

8. Cibes, H. R. and Gaztambide, S., 1978. Mineral deficiency symptoms displayed by papaya plants grown under controlled conditions, J. Agric. Univ, P.R. 62 (4): 413-23.

9. Godoy, J. D., Kocher, F. and Villalobos, A., 1969. Efecto de la fertilización nitrogenada en la curva anual de nitrógeno en papayos (Carica candamarcensis Hook, f). Agric. Téc. (Chile) 29 (1): 9-14.

10. Jones, W. W. and Storey, W. B., 1941. Propagation and culture of the papaya, Hawaii Agric. Exp. Stn. Bull. 87.

11. Jones, W. W., Storey, W. B., Paris, G. K. and Holdaway, F. G., 1941. Papaya production in the Hawaiian Islands, Hawaii Agric. Exp. Stn. Univ. Hawaii, Bull. 87.

12. Kocher, F. and Villalobos, A, 1966. Compración entre los constituyentes nitrogenados de hojas como indicadores del estado de nutrición nitrogenada de la planta, Agric. Téc. (Chile) 26 (4): 155-58.

13. Muñoz, I., Kocher, F. and Villalobos, A., 1968. Determinación de las concentraciones críticas de fósforo y boro para el crecimiento del papayo (Carica candamarcensis Hook f). Agric. Téc. (Chile) 28 (3): 119-24.

14. Muñoz, M., Kocher, F., and Villalobos, A., 1966. Síntomas de deficiencias nutricionales en plantas de papayo (Carica candamarcensis Hook f). Agric. Téc. (Chile) 26 (3): 106-13.

15. Pérez-López, A. and Childers, N. F., 1982. Growth, Fruiting and Nutrient content of Carica papaya L. under controlled conditions. I. Nitrogen Effects. J. Agric. Univ. P.R. 66 (29: 00 .

16. Smith, $P$, 1966. Citrus nutrition, a chapter in Fruit Nutrition-Temperate to Tropical, N. F. Childers, Ed, Hort. Publ., New Brunswick, N.J.

17. Traub, H. P., Robinson, 'T. R. and Stevens, H. E., 1942. Papaya production in the United States, USDA Cir. 633.

18. Tripathi, R. D., 1957-59. A review of papaya manuring, Annu. Rep. Fruits Exp. Stn., Saharanpur, India.

19. Effect of N, P and K fertilizers on papaya vigor. Hort. Absts, 33 (1): 1817. 